\title{
Influence of Promotional Prospects on Turnover Intentions of Public Secondary School Teachers in Meru County
}

\author{
Peter Kalunge Ekabu \\ Grace Nyagah \\ Jeremiah.M. Kalai \\ Department of Educational Administration and Planning, \\ University of Nairobi, Kenya
}

Doi:10.19044/esj.2018.v14n25p17 URL:http://dx.doi.org/10.19044/esj.2018.v14n25p17

\begin{abstract}
The importance of motivation in retaining core employees and reducing turnover intention in any organization cannot be underestimated. Therefore, retaining the best teachers in secondary schools continue to be a major challenge for educational managers in Kenya as teachers keep changing careers or are not fully committed to their duties because psychologically majority have their hearts elsewhere. This study aimed at examining the influence of promotional prospects on turnover intentions of public secondary school teachers in Meru County. The study used a descriptive survey design with both quantitative and qualitative approaches in data collection and analysis. A total of 520 respondents were involved in the study. Teacher promotional prospects, was examined to determine its relationship with the dependent variable, turnover intentions. Data obtained from questionnaires were analyzed quantitatively using SPSS version 21. Hypothesis was tested using Pearson product moment correction coefficient and chi-square goodness of fit at $95 \%, \mathrm{p}<0.05$.

The results from product moment correction showed that the independent variable; promotional prospects $(\mathrm{r}=-0.524, \mathrm{p}<0.001)$, has a negative and an inverse relationship with the dependent variable, turnover intention. The Chisquare analysis corroborated the Pearson correlation results by showing a significant relationship between promotion prospects and turnover intentions of secondary school teachers in Meru County. The results concluded that teachers' motivation in secondary schools in Meru County is low with teachers having poor morale and low levels of commitment to their job due to lack of promotion and stagnation in one grade hence high turnover intentions set in. The study recommends that the Teachers Service Commission of Kenya,
\end{abstract}


consider issues of promotion of teachers in motivating and reducing turnover intentions hence retention in teaching service.

Keywords; Turnover intentions, Promotional prospects, Motivation

\section{Background of the Study}

Employee turnover in an organization mainly occurs due to failure of management to motivate employees (Mba \& Ikemefuna, 2011).Many teachers in Sub-Saharan Africa are poorly motivated hence leading to low levels of job satisfaction, and ultimately poor quality teaching in schools (Gatsinzi, Jesse, \& Makewa, 2014). Bennell and Akyeampong (2007) contend that this leads to teacher motivation crisis related to issues of poor salary, lack of advancement on promotion, lack of recognition, poor school facilities and discipline issues among students. Additionally, due to lack of motivation, teachers lack accountability in their work and low job satisfaction resulting in turnover intentions (Bennell, 2007). Mary (2010) notes that most teachers in Africa are not motivated because of poor working conditions and inadequate incentives such as promotional prospects. Hence teachers in these countries are disgruntled with poor working conditions and this disgruntlement may lead to eventual exit from the teaching profession. Promotional prospects are the perception of teachers on the chances an employee (teacher) has for promotion or gaining a better position within the same organization (TSC) or progressing in his or her teaching career.

Motivation is an important tool for elimination of negative turnover within organizations (Martin, 2011; Nyamubarua, 2013). In organizations where there is inadequate human resource behavior motivation, there are no clear goals, and therefore organizational inefficiency which lead to employees intending to or leaving the organization altogether (Martin, 2011).Various factors such as level of remuneration, promotion and staff development opportunities, conditions of work environment, supervisors management style, work safety and relationship with colleagues have been found to determine turnover intention in educational institutions (Hackman \& Oldham,1980).

Many studies (Souza-posa \& Hennenberger, 2004; Isaac et al, 2015: Jonathan et al, 2013; Oluwafeni, 2013) have found that turnover intention predict actual turnover. Therefore studying turnover intentions is more important than studying actual turnover because turnover intentions are often the final outcome variable in turnover studies and measuring it is easier and usually more accurate (Lambert \& Hogan, 2009). Furthermore, accessing employees who quit their jobs to ascertain why they left is a difficult task which makes studying of turnover intention more useful for an organization compared to the study of actual turnover. 
Additionally, employees (teachers) contemplating of leaving may still be persuaded to remain by improvement in work environment, yet it might be too late for those who have already left employment to be brought back (Chiboiwa, Samuel, \& Chipunza, 2010; Lambert \& Hogan, 2009; Samuel \& Chipunza, 2009). It is therefore justified to study teacher turnover intentions because it can serve as a bold move in identifying and solving some problems in schools that are related to actual turnover. Furthermore, high level of employees (teachers) turnover intentions even when it does not result in actual turnover has been found by many researches to have adverse effects on employee performance, work withdrawal and general organizational performance (Abassi, Hollman \& Hayes, 2008; Oluwafeni, 2013).

\section{Objective}

The objective of the study was to establish the relationship between promotional prospects and turnover intentions of secondary school teachers in Meru County.

\section{Study hypothesis}

The null hypothesis for the study was: There is no significant relationship between promotional prospects with the Teachers Service Commission and turnover intentions of secondary school teachers in Meru County.

\section{Literature Review}

Relationship between promotional prospects and turnover intentions

In order for an organization to survive, it must strive to retain professionals by reducing mobility of their workforce through offering promotional rewards (Kim, 2012). When employees perceive promotion opportunities outside their current organization while at the same time perceiving little or no promotion prospects in their current organization is a good reason for them to think of leaving (Stahl, Chua, Caligiuri, Cosdin, \&Taniguchi, 2009).Therefore an employee's perception of a promotional prospect within an organization is one of the very important factors that influence employee intention to remain or quit an organization. This is because employees feel more motivated to work in organizations which provide them with promotional prospects to new challenging positions. Conversely, if an employee stagnates in one position for long, he or she is not motivated and therefore unlikely to stay in such unfulfilling jobs (Kinyili et al, 2013). Employee promotion leads to increased pay, higher status, and higher selfesteem resulting in increased job satisfaction unlike those employees who stagnate in the same position. Therefore employees' turnover intentions are lower in organizations where there are clear career growth paths than in 
organizations where employees' careers are static with little or no promotional prospects (Nyamubarua, 2013; Ng'ethe, 2013; Lambert, \& Hogan, 2009).

Lack of an employee growth in an organizations leads to career plateau resulting to rise in turnover intention because such employees want to advance their career elsewhere in the environment (Kinyili et al, 2013; Lee, 2003; Ongori and Agola, 2009).The aim of promotional procedures of an organization should enable employers to get the best available talent in an organization to occupy senior positions. This provides employees with a chance to progress within the organization hence more motivated reducing turnover intentions (Armstrong, 2010; Kipkebut, 2010).

According to Weng, McElroy, Morrow and Liu (2010), employee career growth in an organization could be described in four ways. First, career goal progress or the degree of relevance of one's present job to provision of opportunities for reaching his/her career goals. Second, the ability of the current job to provide professional development through acquiring of new skills and knowledge. Third, promotion speed or the perceptions an employee has on the rate and possibility of getting promoted in their current organization. Finally, remuneration growth or the perception an employee has on the speed, amount as well as the possibility of an increase in compensation.

A study by Weng \& McElroy (2012) on career growth and its influence on organizational commitment and turnover intentions found that career growth dimensions were negatively related to turnover intentions and effective occupational commitment was found as a partial (mediation) on other relationships. Literature available indicates that organizations that provide good environment for career growth through supporting them achieve their career goals by improving their skills and knowledge, awarding regular promotions as well as good remunerations, such employees would reciprocate by enhancing a moral obligation to work hard for their organizations and therefore think less about resignation or intention to leave (Weng \& McElroy, 2012; Weng, McElroy, 2010).

Kim (2014) explained the importance of career advancement in reducing turnover intentions by alluding that turnover intention among workers is reduced significantly when such employees perceive career advancement opportunities in their current employment. Chang et al (2017) supports this position by claiming that organizations that satisfied the needs of its employee through career development and promotions, such organizations managed to reduce turnover intentions of such employees significantly. Savickas (2011), showed that many young employees tend to give more emphasis to career growth and tend to leave an organization that have no prospects for growth for an organization that offers prospects for career growth. Therefore employees who perceive their organizations interests in their career growth through staff development opportunities and promotion 
positively respond in the development of the organization leading to low turnover intentions (Wang et al, 2014).

Promotion and advancement opportunities influence employee job satisfaction. Various studies (Junaidah, Nazimi, \& Zainuddin, 2010; Danish \& Usman, 2010) reported a positive relationship between promotional opportunities and job satisfaction. Chen (2006) found a negative relationship between measures of promotional frustration and measures of attitude towards a company. This implies that if employees perceive a possibility of or a path to be promoted within an organization, they will be more satisfied with their current job as the promotion assures them of more responsibilities and higher compensation resulting to lower turnover intentions (Baibaita, Salihu, Salami, \& Alao, 2016).Armstrong (2010) concurs by positing that promotion opportunities offer employees a chance to advance in an organization hence an important motivator which reduces turnover intention enhancing employee retention.

Steven (2010) postulates that promotion opportunities in an organization stimulates personal development among employees leading to enhancement of interest in the job. On the other hand, when such employees stagnate in their current positions, their motivation to stay in such positions usually nosedive and would most certainly not remain in such unfulfilling positions (Steven, 2010).This is because as found in many studies, promotion usually comes with increased remuneration, higher status, boosted self esteem leading to more authority, responsibility, independence as well as higher job satisfaction. Hameed and Asin (2013) concurs by arguing that promotion of employees provides incentives to initiate enterprises and ambition as well as minimizing discontent and industrial unrest, leads to attraction of capable individuals, necessitates logical training for advancement which results to an effective reward loyalty, cooperation and long service in one's career.

A study by Owhondah (2016) found a strong correlation ( $\mathrm{Rho}=0.823$, $\mathrm{p}=0.000$ ) between promotion and turnover intentions. However the study was done on selected oil firms in Rivers state of Nigeria while the current study was done in public secondary schools in Meru County. Another study by Miringu (2017) found a strong and negative correlation $(r=-0.853, p<0.002)$ between career progression and labor mobility intentions of teaching personnel in Teachers Service Commission tertiary institutions in Kenya. However, this study was focused on teachers in tertiary institutions while the current is mainly focused on public secondary school teachers.

A study by Bennell and Ntagaramba (2008) found that 39 percent of secondary school teachers in Rwanda were increasingly de motivated due to low prospects for promotion within the teaching force among other factors hence high turnover intentions. Literature available indicates that when an employee motivation is low, work performance reduces. Ingersoll (2001), for 
example concluded that lack of community support, poor opportunity for professional advancement on promotion, political meddling in teaching profession, large class sizes, student indiscipline, low administrative support and unsafe work environment as major causes of demotivation, poor performance and low job satisfaction within the teaching profession resulting to high turnover intensions.

Asif, Hassan, and Ramzan (2013) did a study on the impact of motivation on employee turnover in telecom section of Pakistani. They used 106 closed ended questionnaires and also used correlation and regression analysis in analyzing data. The result of the study indicates motivation as a significant predictor of decrease of employee's intention to leave. According to Glewwe, Hamishek, Humpane and Ravina (2011), schools are factories that help in producing learning through schooling and teaching characteristics (inputs).They further lament that if education system provides quality inputs (teachers), then it is possible to produce quality outputs or products (students) which is only possible if the teaching profession is made attractive as well as desirable by meeting teachers' needs such as improving their job satisfaction and motivation. Moreover teachers will not quit or think of quitting their jobs if their pay is high or at least equal to that offered to other professions, if they are offered job security, if their schools are well equipped and good working environment with favorable workload, when they are appreciated for their good work, as well as being provided with training and development opportunities and promotional opportunities (Aslam, 2013).

A study by Benjamin and Ahmad (2012) on motivational factors leading to employee retention and engagement in organizations showed that the most important factors influencing employee retention are financial rewards, teacher promotional opportunities, career development opportunities as well as recognition. The study further recommended that organizations should formulate suitable retention strategies through enhancing motivation to reduce turnover rates for its employees. These sentiments are supported by other studies (Achoka, Popoi, \& Sirma, 2011; Kafu, 2011) which have identified low status of teaching profession, poor remuneration, constant ridicule in the media and the public, work overload, and deplorable working conditions have created a lot of despair amongst Kenyan teachers and many of them would quit teaching if an opportunity arises .

\section{Methodology \\ Research design}

A cross-sectional descriptive survey design was used for this study. It employed both quantitative and qualitative approaches in data collection and analysis. According to Babbie (2010), a cross sectional survey method is the most commonly used research method in social research as the results of such 
a survey can be easily applied or extrapolated to the entire population because it involves observations of a sample or cross-section of a population or phenomena that are made at one point in time. Additionally, this method is less costly and time saving since it allowed the researcher to use questionnaires to collect large amount of data from sampled population given the fact that the study population is big and geographically spread covering the whole of Meru County. The use of both quantitative and qualitative approaches in data collection enabled the removal of biasness since the two approaches help to check one another whereby the subjectivity associated with qualitative research is minimized by the objectivity of quantitative approach (Mugenda $\&$ Mugenda, 2003).

\section{Target population}

All secondary school teachers including all the principals in public secondary schools in Meru County were targeted in the study. Meru County has a total of 367 public secondary schools and a total of 2582 teachers employed by the Teachers Service Commission. The study also involved eight (8) Teachers Service Commission staffing officers from various sub-counties in Meru County.

\section{Sample and sample size}

Proportionate stratified sampling was used in this study because it involves the selection of individual sampling unit of a sample that is proportionate to the size of the unit which increases chances of sample representativeness (Singh \& Singh, 2012; Orodho, Khatete, \& Mugiraneza, 2016). These strata included boarding schools (88) and day schools (269). Simple random sampling was used within each stratum to select the samples to avoid biasness and ensure equal representation of the subgroups in the sample. This ensured the desired and unbiased representation from the various sub-groups in the population (Mugenda \& Mugenda, 2003: Kothari 2004; Orodho, Khatete, \& Mugiraneza, 2016).

Twenty percent of the schools used for the study in each sub-county were selected based on the number of schools in each sub-county as proposed by Gay, Mills, and Airasian (2009), and Mugenda and Mugenda (2003) who contend that social researchers recommend that 10 percent to 30 percent of the accessible population is enough and at least 30 cases are required per group for statistical data analysis. Based on this, 73 secondary schools (55 day and 18 boarding) which are 20 percent of the total number of schools were used in the study. With a total population of 2,582 teachers in Meru County, the sample size was determined through the same method. Therefore 516 teachers were selected for this study. 


\section{Research instruments}

Questionnaires were used to collect quantitative data from teachers, while interview schedules were used to collect qualitative data from selected principals. A closed ended questionnaire was designed to address the research objective and test hypothesis (Mugenda \& Mugenda, 2003).A closed ended questionnaire inform of 5-Likert scale based on a five point rating ranging from strongly agree to strongly disagree were administered to teachers who participated in the study.

\section{Validity and reliability}

Instrument content validity was improved by expert judgment. The researcher issued copies of questionnaires to his two supervisors who went through them and gave the necessary advice on areas of improvement hence making the instrument more valid. Reliability (internal consistency) of the questionnaires was determined using Cronbach's alpha reliability coefficient method through the help of SPPS version 21 which yielded a coefficient of (0.725). As a rule of thumb, many researchers contend that alpha values of 0.70 or above are acceptable (Des vaus, 2002; Maizura, Malamani \& Aris, 2009). Therefore based on this suggestion, the instruments were deemed to be reliable.

\section{Data analysis techniques}

All completed questionnaires were checked for completeness. Then the data obtained through questionnaires were categorized, coded and entered into computer to generate quantitative data. After data cleaning, descriptive statistics such as the mean, standard deviation and percentages were estimated for all the items of the variables of study. Descriptive statistics enabled the researcher to meaningfully describe distribution of scores using a few indices (Mugenda \& Mugenda, 2003).The report of the analysis on the Likert scale results were done descriptively through what is referred to as the "collapsing response" by Gwavuya (2011) by adding the responses of strongly disagree percentage with those of disagree responses $(\mathrm{SD}+\mathrm{D})$ and the strongly agree with the Agree (SA+A) and also the mean and standard deviations of all the variable items. Statistical packages for Social Sciences (SPSS) version 21.0 was used to assist in data analysis. Questions used to collect qualitative data from interviews were aligned to the research objectives. The data collected from semi structured interview, were analyzed qualitatively whereby the hand written notes of the interview and document analysis were transcribed, categorized, summarized and compiled into common themes according to objectives and the qualitative findings were integrated into the quantitative findings from the questionnaires in the final report.

Inferential statistics were also computed in the second stage of data analysis to test the stated hypothesis of the study. Chi-square goodness of-fit 
and Pearson Product-Moment Correlation Coefficient (r) were used to test hypotheses at 95 percent level of confidence and 5 percent level of precision. Chi-square was used to determine the significance levels of relationships between variables. According to Saunders et al (2009), a Chi-square test helps a researcher to establish how likely the two variables are associated. Pearson product moment correlation (r) was used to determine or test the strength and direction of relationship between variables. This is because Pearson Product Moment Correlation Coefficient ( $r$ ) is a very useful statistical tool in testing the strength of relationship of the study variables as proposed by many authors such as (Mugenda \& Mugenda, 2003; Saunders et al, 2009).

\section{Results and discussions}

The objective of the study was to establish the relationship between promotional prospects and turnover intentions of secondary school teachers in Meru County. Five items were used to study this objective on a Likert scale 1 to 5 ranging from 1-strongly agree to 5-strongly disagree as shown on Table 1

Table 1 Relationship between promotional prospects and turnover intentions

\begin{tabular}{|c|c|c|c|c|c|c|c|c|}
\hline & Mean & SDev & $\mathrm{N}$ & $\begin{array}{l}\text { SA } \\
(\%)\end{array}$ & $\begin{array}{l}\mathrm{A} \\
(\%)\end{array}$ & $\begin{array}{l}\mathrm{ND} \\
(\%)\end{array}$ & $\begin{array}{l}\mathrm{D} \\
(\%)\end{array}$ & $\begin{array}{l}\text { SD } \\
(\%)\end{array}$ \\
\hline $\begin{array}{l}\text { Teachers promotion are not regular with my } \\
\text { employer }\end{array}$ & 1.79 & .903 & 500 & 46.7 & 34.4 & 13.1 & 5.2 & 0.6 \\
\hline $\begin{array}{l}\text { Am planning to leave teaching as there are no } \\
\text { promotional prospects compared to other } \\
\text { professions }\end{array}$ & 2.26 & 1.131 & 500 & 27.9 & 39.9 & 15.0 & 12.6 & 4.6 \\
\hline $\begin{array}{l}\text { I am not motivated to stay in this school } \\
\text { because there are no good chances of being } \\
\text { promoted here }\end{array}$ & 2.18 & 1.020 & 500 & 28.7 & 38.0 & 20.9 & 10.8 & 1.6 \\
\hline $\begin{array}{l}\text { Promotions are not always based on merit in } \\
\text { my employer }\end{array}$ & 2.08 & .963 & 500 & 33.8 & 32.6 & 26.0 & 7.0 & 0.6 \\
\hline $\begin{array}{l}\text { Despite attending a number of promotional } \\
\text { interviews with the Teachers Service } \\
\text { Commission, have never been promoted, } \\
\text { hence if I got another job where there are } \\
\text { prospects for promotion, I would quit } \\
\text { teaching immediately }\end{array}$ & 2.23 & 1.213 & 500 & 34.8 & 30.6 & 19.5 & 7.8 & 7.4 \\
\hline
\end{tabular}

The descriptive results also indicate that 66.7 percent of the respondents strongly agreed and agreed that they are not motivated to stay longer in their current schools because there were no good chances of being promoted there, while only 12.4 percent strongly disagreed and disagreed with 20.9 percent of the respondents not sure. The mean rating for this item was 2.18 and a standard deviation of 1.020 implying that majority of secondary 
school teachers in Meru County are not intending to remain teaching in their present institutions because they believe they have no chances of getting promotions while in those institutions and therefore would move immediately an opportunity for another better job or school arises.

The descriptive results indicate that 66.4 percent of the respondents strongly agreed and agreed that teachers' promotions are not always based on merit, while only 7.6 percent strongly disagreed and agreed. A significant number (26 percent) of the respondents were not sure. This item had a mean rating and standard deviation of 2.08 and 0.963 respectively implying that majority of secondary school teachers in Meru County do not believe that Teachers Service Commission offers promotions on merit meaning that promotions are not based on how hard a teacher works but is determined by other factors. However a curious (26 percent) of the teachers in Meru County are not very sure whether promotions are offered on merit or not. These could be mainly the newly employed teachers who could be swayed either way with time.

The results also indicate that 65.4 percent of the respondents strongly agreed and agreed that although they attended a number of promotional interviews with the Teachers Service Commission, they have never been promoted; hence if they got another job with more prospects for promotion, they would immediately quit teaching. Only a paltry 15.2 percent of the respondents disagreed and strongly disagreed and another 19.5 percent were not sure. The item had a mean rating of 2.23 and standard deviation of 1.213.This agrees with a study by Wambugu (2015) who found that secondary school teachers in Nairobi County were dissatisfied with their promotion is conducted ( mean,2.3171 and standard deviation of 0.982). These results therefore shows that majority of teachers in secondary schools in Meru County have stagnated in one job group for long and have no promotional prospects with the Teachers Service Commission and would move to another job which offers better promotional prospects if such an opportunity arises.

From the interview, most principals reported that promotion of teachers is a very serious issue as many teachers including principals themselves stagnate in one job group for long with some having to retire without being promoted for a single grade apart from the general grade ( $\mathrm{K}$ and L). Although Teachers Service Commission policies indicate that teachers should be promoted on the basis of their qualifications and years of service using various schemes of service for teachers available, many teachers apply for the few vacancies advertised but are never promoted even after severally attending interviews. This seriously demotivates teachers especially when they compare themselves with their peers in other public service sector where promotions are regular and where career paths are clear making such workers be sure of a promotion after a certain period of time. Principals reported that, 
when teachers compare themselves with other professionals where promotions are almost automatic, they start working hard to move out of teaching profession by searching for jobs elsewhere or even going for further studies to change careers.

A principal in a day secondary school had this to say:

Teachers are not promoted apart from the common cadre job groups ( $\mathrm{K}$ and $\mathrm{L}$ ).

A classroom teacher to move to job group $\mathrm{M}$ and above is a very difficult task unless one is in administrative position. Teachers attend promotional interviews severally without being promoted especially if one is teaching in a day school which is not well endowed with good infrastructure and bright students who can perform in examinations and co-curricular activities. Such teachers keep on looking for transfers to well-endowed schools where chances of promotions are high due to good performance in examinations and co-curricular activities. Some have even gone for further studies to improve their chances of changing jobs.

This is in agreement with Sharma and Bajpai (2010) who assert that employee satisfaction with promotional opportunities depends on factors such as the probability that employees perceive fairness in promotion process such as timing of promotion after meeting the required standards. Therefore the dissatisfaction with lack of promotional opportunities makes many teachers think of quitting teaching whenever an opportunity for another job arises. Principals also reported that most teachers see teaching as a stepping stone to other jobs or professions and others first choose teaching because of flexible working schedules which allow them to attend family and private business. However, due to recent policy changes by the Ministry of Education and the Teachers Service Commission through performance contracting and performance appraisal, working conditions have changed where teachers have a lot of paperwork, congested classrooms and more scrutiny by Government agencies making teachers have no breathing space. This has seriously demotivated teachers especially when combined with lack of promotion and job stagnation which make most of them think of shifting from teaching if another job opportunity arises. According to principals, teaching is not held in high status as other professions like medicine or engineering. They cited stagnation in one job group, lack of job autonomy and a lot of intimidation by various education stakeholders such as the Ministry of Education and the Teachers Service Commission officials, parents, students' indiscipline as well as politicians. One principal had this to say:

I was surprised when four of my six teachers came to my office for a recommendation for a job of Chief Education Officer, advertised by the Ministry of Education. When I inquired from them, they told me they are not happy with teaching as there are no prospects for promotion. Some of the teachers vented their frustration with the T.S.C for not being promoted and stagnating in job group L for 9 years although they acquired Masters Degree. One teacher even said that he is tired of mean score and would like to change the job. 


\section{Inferential statistics}

The second part of data analysis involved generation of inferential statistics through testing of research hypothesis. The null hypothesis: There is no significance relationship between promotion prospects and turnover intentions of secondary school teachers in Meru County was tested using Pearson Product- Moment Correlation Coefficient and chi-square goodness of fit at 95 percent level of significance and 5 percent level of precision. The null hypotheses suggest that the independent variable, promotional prospects and the dependent variable, turnover intention are independent of one another. The researcher was interested in finding out whether there was any relationship between promotional prospects and turnover intentions of secondary school teachers in Meru County. Pearson Product Moment Correlation Coefficient (r) was used to test the strength and direction of relationship between the independent variable (promotional prospects ) and the dependent variable (turnover intention) while chi-square was used to determine the significant level of relationship between the two variables, the independent and the dependent variable.

\section{Pearson correlation results between teacher promotional prospects and turnover intentions of secondary school teachers}

The correlation results are as shown in Table 2 .

The results indicate a significant and negative correlation $(\mathrm{r}=-0.524, \mathrm{p}<0.001)$. This means that promotional prospects and turnover intentions amongst secondary school teachers in Meru County have a strong and significant negative correlation. This implies that an improvement in promotional prospect for secondary school teachers in Meru County leads to a corresponding decrease in turnover intentions and the reverse is true. These findings are in agreement with the findings by Khan and Qadir (2016) who found a significance inverse relationship $(r=-0.726, p<0.01)$ between career growth opportunities and teacher turnover intentions in Bahria schools and colleges at Karachi, Pakistani.

The results confirm that, as seen in the literature review, when opportunities for promotion improve in the current work station, turnover intentions reduce. A study by Weng and McElroy (2012) on career growth and its influence on organizational commitment and turnover intentions in particular found that career growth dimensions were negatively related to turnover intentions. Literature available indicates that promotion and advancement opportunities influence job satisfaction and turnover intentions. For example researchers Junaidah, Nazini, \&Zainudin, 2010; Danish \& Usman, 2010; Chen, 2006) found a significant relationship between promotion opportunities and job satisfaction hence turnover intentions. This implies that 
employees are more satisfied with their current job if they see a path available to move up the ranks in the organization leading to reduced turnover intentions.

Table 2. Pearson Correlation between promotional prospects and teacher turnover intentions.

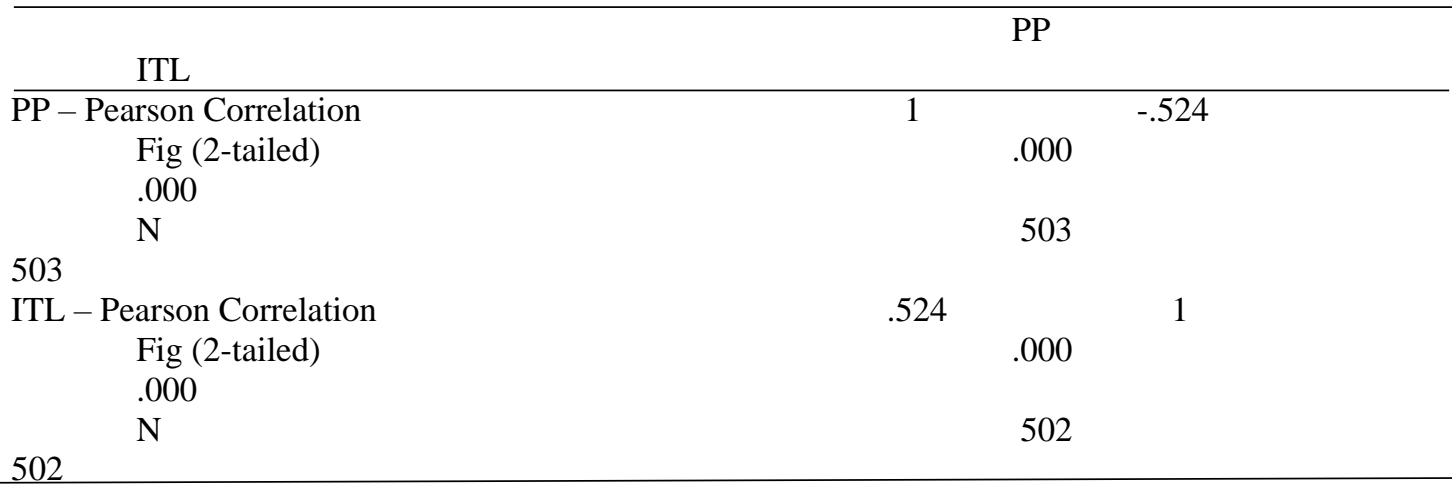

Chi-square analysis between promotional prospects and teacher turnover intentions

The results of test of hypothesis by chi-square for the promotional prospects as shown in table 3 concur with these results of Pearson Product Moment Correlation by showing that the Pearson Chi-Square of 91.842 with 4 degrees of freedom and associated p-value (Asymptotic significance) was 0.000 which is very highly significant at $p<0.005$.This is an evidence against stated null hypothesis which led to its rejection and concluded that there is a significant relationship between promotional prospects and turnover intentions of secondary school teachers in Meru County. The results imply that if teachers perceive the likelihood of prospect for promotion with their employer, they will have little thought of leaving the profession and vice versa. The findings are in tandem with the findings of Owhondah, Onuoha, and Akhigbe (2016), who found a significant relationship between promotion and turnover intentions a position also taken by other researchers such as Aydogdu and Asikgil (2011) who alluded that if employees feel that there are no avenues for promotion in their current jobs, they will be dissatisfied and demotivated hence would think of quitting their current job. 
Table 3 Chi-square results for the promotional prospects and turnover intentions Crosstab

\begin{tabular}{|c|c|c|c|c|c|c|}
\hline & & & $\begin{array}{l}\text { PP.Cat } \\
\text { Low }\end{array}$ & Medium & High & Total \\
\hline \multirow[t]{9}{*}{ ITL.Cat } & Low & Count & 18 & 15 & 8 & 41 \\
\hline & & $\%$ within ITL.Cat & $43.9 \%$ & $36.6 \%$ & $19.5 \%$ & $100.0 \%$ \\
\hline & & $\%$ within PP.Cat & $4.3 \%$ & $22.1 \%$ & $44.4 \%$ & $8.2 \%$ \\
\hline & Medium & Count & 55 & 25 & 5 & 85 \\
\hline & & $\%$ within ITL.Cat & $64.7 \%$ & $29.4 \%$ & $5.9 \%$ & $100.0 \%$ \\
\hline & & $\%$ within PP.Cat & $13.2 \%$ & $36.8 \%$ & $27.8 \%$ & $16.9 \%$ \\
\hline & High & Count & 343 & 28 & 5 & 376 \\
\hline & & $\%$ within ITL.Cat & $91.2 \%$ & $7.4 \%$ & $1.3 \%$ & $100.0 \%$ \\
\hline & & $\%$ within PP.Cat & $82.5 \%$ & $41.2 \%$ & $27.8 \%$ & $74.9 \%$ \\
\hline \multirow[t]{3}{*}{ Total } & & Count & 416 & 68 & 18 & 502 \\
\hline & & $\%$ within ITL.Cat & $82.9 \%$ & $13.5 \%$ & $3.6 \%$ & $100.0 \%$ \\
\hline & & $\%$ within PP.Cat & $100.0 \%$ & $100.0 \%$ & $100.0 \%$ & $100.0 \%$ \\
\hline
\end{tabular}

Chi-Square Tests

\begin{tabular}{llll}
\hline & & & $\begin{array}{l}\text { Asymptotic Significance (2- } \\
\text { sided) }\end{array}$ \\
\hline Pearson Chi-Square & Value & df & .000 \\
Likelihood Ratio & $91.842^{\mathrm{a}}$ & 4 & .000 \\
Linear-by-Linear Association & 73.015 & 4 & .000 \\
N of Valid Cases & 85.140 & 1 & \\
\hline a. 2 cells (22.2\%) have expected count less than 5. The minimum expected count is 1.47.
\end{tabular}

\section{Summary and Conclusion}

The results of quantitative descriptive results show that majority of public secondary school teachers in Meru County are not happy with their employer, Teachers Service Commission because of its inability to offer them promotions making many of them stagnate in one job group leading to high turnover intentions. These results were corroborated by the qualitative results from interviews with the principals. The inferential statistical results (Pearson's Product-Moment Correlation) also show that promotional prospects and turnover intentions of secondary school teachers in Meru County have a significant negative (inverse) correlation( $\mathrm{r}=-0.524, \mathrm{p}<0.001)$ meaning that an increase in promotional prospects of teachers by Teachers Service Commission reduces teacher turnover intentions and vice versa. The Pearson Chi-Square test hypothesis $(91.842$ with 4 degrees of freedom, $\mathrm{p}<0.000)$ also concludes that there is a significant relationship between promotional prospects with the Teachers Service Commission and turnover intentions of secondary school teachers in Meru County implying that many secondary school teachers have high intent of leaving teaching because of slim promotional prospects in the profession. Generally, these results agree with the literature reviewed that indeed, lack of promotional prospects or opportunities within teaching profession is a major source of turnover intentions of secondary school teachers. 


\section{Recommendations}

There is need for the Teachers Service Commission to fast track the promotion of teachers to enhance job satisfaction and reduce turnover intentions. This should be done regularly to make teachers have confidence in teaching and reduce turnover intentions. The policy on promotion of teachers should be revised to enable teachers who attain higher qualifications such as masters and doctoral degrees get automatic promotion. This will enable the most educated and experienced teachers who may opt out of teaching be retained hence reducing turnover intentions. Although rewards in form of salaries is being addressed by Teachers Service Commission, the study recommends the enhancement of existing allowances offered to teachers as well as adding new allowances such overtime allowance, extraneous allowances among others given the fact that the work that teachers do is enormous including but not limited to working at night, weekends as well as marking students scripts and controlling discipline which sometimes may lead to serious confrontations resulting to disastrous outcomes mainly on the teacher.

\section{References:}

1. Abbasi, S.M. , Hollman, K.W.,\& Hayes, R.D. (2008). Bad bosses and how not to be one. Information management journal. 42, 52-56.

2. Achoka, J.K., Poipoi, M.W.,\& Sirma, L.M. (2011).Motivational factors influencing public secondary school teachers to join teaching profession in Busia district,Kenya.International journal of current research, Vol.3(4),059-068

3. Armstrong, M.A. (2010). Handbook of human management practices $\left(13^{\text {th }}\right.$ Ed.).London, Kogan page

4. Asif, S., Hassan, G., \&Ramzan, M. (2013).Impact of motivation on employee turnover in the Telcom sector of Pakistan. Journal of business studies quarterly: vol 5 (1), 76-91

5. Aslami, H. (2013).Teacher Attrition: Why Secondary School Teachers Leave the profession in Afganistan. Master of Education Thesis in International

6. Educational Policy, Research and Administration. University of Massachusetts, Amherst.

7. Ayodogu, O., \& Asikgil, B. (2011).”An empirical study of the relationship among job satisfaction, organizational commitment and turnover intention". International

8. Babbie, E.R.(2010).The Practice of Social Research $\left(12^{\text {th }} \mathrm{ed}\right)$. Wadsworth, London: Centage Learning.

9. Baibata, I.S., Salihu ,A.N., Salami, A.I.,\& Alao,S.T.(2016).Effects of Job Satisfaction on employee Turnover Intention in flour mills of 
Nigeria PLC, Lagos. Sahel Analyst: Journal of Management Sciences, Vol.14(1),University of Maiduguri

10. Benjamin, B.A., \& Ahmad, P.S.(2012).Motivational Factors of Employees Retention and Engagement. International Journal of Advances in Management and Economics, 1 (6), 88-95.

11. Bennel, P.,\& Akyeampong, K.(2007).Teacher motivation in Subsaharan Africa and SouthAsia.Education papers.Retrieved fromwww.dfd.gov.uk/R4D/PDF/outputs/policystrategy, Researching.

12. Bennel, P.,\& Ntaragamba, J.(2008).Teacher Motivation and Incentives in Rwanda. A Situational analysis and recommended priority action.

13. Chang, P.L., Chou, Y. C., \& Cheng, F.C. (2007).Career needs, career development programs, organizational commitment and turnover intentions on nurses in Taiwan .Journal of management, 15, 801-810.

14. Chen,C.(2006). Job Satisfaction, Organizational Commitment and flight attendants, turnover Management a note. Journal of Air transport Management.12,274-396

15. Chiboiwa,W.M., Samuel, M.O.,\& Chipunza, J. (2010). An examination of Employee Retention Strategy in a private Organization in Zimbabwe. African Journal of Business Management, 4(10), 2103 2109.

16. Choi,L.S., Perumal, P., \& Akintunde, M.A.(2012). The Impact of Human Resource Management Practices on Employee Turnover Intentions; A Conceptual Model. International Journal of Contemporary Research Business. 4,629-637

17. Danish, R.Q.,\& Usman, A.(2010).The Impact of Reward and Recognition on Job Satisfaction and Motivation: An Empirical study from Pakistan. International Journal of Business and Management,5(2),157-167

18. De vaus, D.A.(2002).Surveys in Social Resaerch(5 $5^{\text {th }}$ ed).London: Routledge

19. Gatsinzi, P., Jesse, R., \& Makewa, L.N.(2014).Work related variables in teacher motivation Gasabo District, Rwanda. Journal of Education and Trining.vol.1, 2

20. Gay,L.R., Mills, G.E., \& Airasian, P. (2009). Educational research: competencies for Analysis ( $9^{\text {th }} e d$ ). New Jersey: Pearson Education.

21. Glewe,P..Hamishek,E.A., Humpane, S.D., Ravina, R.(2011).School Resources and Educational Outcomes in developing countries: A Literature Review from 1990 to 2010. Cambridge Mass. National Bureau of Economic Research, Working paper.17554:http://www.nber.org/papers/w17544 
22. Gwavuya, F.(2011).Leadership influences on turnover intentions of Academic staffing Zimbabwe. Academic Leadership Journal, 9(1), 115.

23. Hameed, M., \&Asin, M.(2013). Impact of promotion on employee motivation in organizations: Specific to Education sector of Pakistan. International journal of scientific and research publications, 3 (9), 2250-3153

24. Hackman, J.R.,\& Oldham, G.R.(1980). Work redesign and motivation Professional Psychologyl1(3) : 445 455.http://dx.doi.org/10.1037/0735-7028.11.3.445

25. Ingersoll, R.(2001).Teacher turnover and teacher shortages. An organizational analysis. American education research journal, 38(3), 499-534.

26. Isaac, K., Ibrahim, S., Janet, S.B., \& Robert, M.(2015). Teacher motivation and job satisfaction on intention to quit. An empirical study in public secondary cycle schools in Tamale metropolis Ghana. International journal of scientific and research publications, 5(5)

27. Jonathan, H., Thibeli, M., \&Darroux, C. (2013). Impact of investigation of organizational commitment on intention to leave of public secondary school teachers in Tanzania. Developing country studies, 3(11), 78-91.

28. Junaidah, K., Zainudin, A., \& Nazmi, R.(2010).Research Methodology for Business and Social Sciences. University Publication Center(UPEMA), UITM.

29. Kafu,P.A. (2011). Teacher Education in Kenya: Emerging issues, International Journal of Curriculum and Instruction, 1(1), 43-52, Available online at http://www.muk.ac.ke/ijci/

30. Khan, R.A., \& Qadir, M.I.(2016). Determinants of Teacher turnover intentions in Bharia Schools and Colleges at Karachi. Journal of Business Studies, 12 (1),198-218

31. Kim, S. (2002). Participative Management and Job Satisfaction: Lessons for management leadership; Public Administration Review, vol. 62. Pp, 231-241

32. KIM, S. (2012). The Impact of Human Resource Management of State Government IT Employee Turnover Intentions. Public Personnel Management, 41(2), 257-279.

33. Kim, N. (2014).Employee Turnover Intention among Newcomers in Travel Industry. International Journal of Tourism Research, 16, 56-64.

34. Kinyili, J.M., Karanja, K., \& Namusonge, G.S. (2015). Role of remuneration and career advancement practices on the retention of employees in organizations. International Journal of Advanced Research in Management and Social Sciences, 4(7)254-276 . 
35. Kipkebut, D.J. (2010). Organizational commitment and job satisfaction in higher education Institutions. The Kenyan case. PhD Thesis, Middlesex University

36. Lambert, E. \& Hogan, N. (2009). The importance of job satisfaction and organizationalCommitment, shaping turnover intent. A test of a casual model. Criminal justice review, volume 34, pp.96-118.

37. Maizura, H., Masilamani, R., \& Aris, T.(2009). Reliability (internal consistency) of the job content questionnaire on job stress among office workers of a multinational company in Kuala Lumpur. Asia-Pacific Journal of Public Health 21(2), 216-222.

38. Makena, F., Ng'ethe, J.M.,\& Mburu, D.K.(2016).Influence of promotion on Human Capital Mobility in Public secondary schools in Nairobi County. International Journal of Human Resource and Procurement, 5(5), 151-166

39. Martin, M.J. (2011).Influence of human resource practices on employee intention to quit. (Unpublished) doctoral dissertation. Virgina polytechnic institute and state university, blackburg, Virginia.

40. Mary, A. (2010) .Motivation and performance of secondary school teachers in Uganda: A case of Kimaanya-Kyebankuza division. (Unpublished PhD Thesis),Uganda, Makerere University.

41. Mbah, S., \& Ikemefuna, C. (2011). Job satisfaction and employee turnover intentions in total Nigeria, PLC, Lagos. International journal of humanities and social science, 2 (14),275-287

42. McCoy, L.P.(2003).It's a hard job. A study of novice teachers. Perspectives on why teachers leave the profession. Current issues in education,6(7).Retrieved on 19/12/2017 from http://c.i.e.edu.asu.edu/volume6/number7/wakeforest

43. Miringu, A.N.,Ngugi, P.K., Were, S.,\& Odhiambo, R.(2017).Does Career Progression Nudge Labour Mobility Intentions of Teaching Personnel in Teachers Service Commission Tartiary Institutions in Kenya? International journal of Academic Research in business and social sciences, 7(1), 141-152

44. Mugenda, O.M.,\& Mugenda, A.G.(2003). Research methods: Quantitative and Qualitative approaches .Nairobi: Acts Press.

45. Muguongo, M.M., Muguna, A.T., \& Muriithi, D.K.(2015).Effects of Compensation on Job Satisfaction among secondary school teachers in Maara Sub-County,Tharaka Nithi County, Kenya. Journal of Human Resource Management, 3(6), 47-59

46. Mugweru, W. (2013).Promotion of secondary school teachers by Gender, Experience and School type, a case of in Kenya. Middle Eastern and African. Journal of Educational Research, Kenyatta University, (6). 
47. Ng'ethe, J.M. (2013). Determinants of academic staff retention in public universities in Kenya. PhD thesis, Jomo Kenyatta University of Agriculture and Technology.

48. Nyamubarwa, W. (2013).I am considering leaving soon"- turnover intentions of Academic librarians in Zimbabwe. Journal of business administration and education, volume 4, no.12013-79-90 of manpower 22(7), 600-624.

49. Oluwafeni, O.J.(2010).Contextual dispositional factors, turnover intention and Perceived job alternatives as predictors of citizen behavior of employees of Nigeria's oil industry. (University of Ibadan, An unpublished Ph.D.Thesis).

50. Oluwafeni, O. J. (2O13). Predictors of turnover intentions among Employees in Nigeria's oil industry. Organizations and Markets in Emerging Economies, Vol.4, No.2 (8).

51. Ongori, H., \& Agolla, J.E. (2009). Paradigm shift in managing career plateau in organizations. The best strategy to minimize employee intention to quit. African journal of business management, 3(6), 268271.

52. Orina, W.A. (2014). Assessment of factors leading to early retirement of public secondary school teachers in Kajiado county, Kenya. A masters of education thesis. The Catholic University of East Africa.

53. Orodho, J.A., Ncabalirwa, W., Odundo, P.,Waweru, P.N.,\& Ndayambaye, I.(2016). Qualitative and Quantitative Research Methods in Education and Social Science: A Step by Step Guide to Scholarly Excellence ( $1^{\text {st }}$ Ed.). Kanezya Publishers and Enterprises, Nairobi, Kenya.

54. Orodho, J.A., Khatete, I.,\& Mugiraneza ,J.P.(2016). Concise Statistics: An illustrative Approach to Problem Solving $\left(1^{s t} E d\right)$ Nairobi, Kanezja Happy land Enterprises.

55. Samuel, O., \& Chipunza, C. (2009). Employee retention and turnover: Using Motivational Variable as a panacea. African Journal of Business Management, 3(8), 410-415

56. Savickas, M.L. (2011).New questions for Vocational Psychology: Premises, Paradymns and practice. Journal of Career Assessment, 19(3), 251-258.

57. Sharma, J.P., \& Bajpai, N.(2010). Organizational commitment and its impact on job satisfaction of employees: a comparative study in public and private sector in India. International Bulletin of Business Administration, 13 (2), 97-118.

58. Singh, M., \& Singh, U,(2012). Research methods in education. New Delhi, University science press. 
59. Stah, G.K., Chua, C.H., Caligiuri, P., Cerdian, J.L.E., \& Taniguchui, M.(2009). Predictors of Turnover Intentions in learning driven and demand driven international assignments. The role of repatriation concerns, satisfaction with company support and perceived career advancement opportunities. Human Resource Management, 48(1), 91 111.

60. Steven, P., \& Zhiang, L.(2010).Promotion systems and organizational performance. A contigency model. Tekleab: Kluwer Academic publishers.

61. Suleiman A, A.,\& Matsom, A.(2013).Employee Dissatisfaction and Turnover Crisis in the Malaysian Hospitality Industry. International Journal of Business and Management, 8(5), 62-71

62. Sutherland,M.M.(2004).Factors affecting the retention of Knowledge Workers.(PhD Dissertation).Faculty of Economics and Management Sciences, University of Johannesberg.

63. Souza-Posa, A., \&Hennenberger, F. (2004). Analyzing job mobility with job turnover intentions: An International Cooperative Study. Journal of economic issues, 38(1), 113-137.

64. Tierney, J. (2012).The Atlantic. Why do so many teachers hate their jobs? Because they hate their bosses. Retrieved from http://www.theatlantic.com/national/archive.

65. Tetty, J.W. (2006).Staff retention in African universities. Elements of sustainable strategy, Washington D.C; World Bank.

66. Urwick, J., Mapuru,,P.,\& Nkhoboti, M. (2005). Teacher motivation and incentives in Lesotho. Maseru Lesotho college of education. University

67. Waititu, G.M. (2013).An analysis of factors influencing turnover of teachers in public high schools in Limuru District, Kenya .Unpublished master of education thesis, Kenyatta University.

68. Wambugu,T.W.,\& Busienei,J.R.(2015).Factors leading to Job Satisfaction of public secondary school teachers in Nairobi County, Kenya. Strategic Journal of Business and Change Management, 2(122), 1988-2008.

69. Wang, et al (2014).Organizational career growth and subsequent voice behavior. The role of effective commitment and gender. Journal of vocational behavior, 84 (1), 431-441

70. Weng, Q.X., McElroy, J.C.,Morrow,P.C,\& Liu,R.(2010).The relationship between career growth and organizational commitment. Journal of Vocational Behavior, 77(3),391-400 